Reyes, A.A. and R.B. Smith. 1986. Controlled atmosphere effects on the pathogenicity of fungi on celery and on the growth of Botrytis cinerea. HortScience 21:1167-1169.

SAS Institute, Inc. 1982. SAS user's guide and SAS statistical procedures. SAS Institute, Inc., Cary, N.C.
Smith, M.A., L.P. McColloch, and B.A. Friedman. 1966. Market diseases of asparagus, onions, beans, peas, carrots, celery, and related vegetables. USDA Agr. Hdbk. 303.

Smith, W. L., Jr., H.E. Moline, and K.S. Johnson. 1979. Studies with Mucor species causing postharvest decay of fresh produce. Phytopathology 69:865-869.
Sommer, N. F., R.J. Fortlage, J.R. Buchanan, and A.A. Kader. 1981. Effect of oxygen on carbon monoxide suppression of postharvest pathogens of fruits. Plant Dis. 65:347-349.

Weimer, J.L. and L.L. Harter. 1921. Glucose as a source of carbon for certain sweet potato storage-rot fungi. J. Agr. Res. 21:189-210.

\section{Postharvest Handling of Physostegia purpurea Cut Flowers}

John W. Kelly ${ }^{1}$

Department of Horticulture, Clemson University, Clemson, SC 29634

Terri W. Starman ${ }^{2}$

Department of Plant and Soil Science, Southern Illinois University, Carbondale, IL 62901

Additional index words. false dragonhead, lion's heart, obedient plant, senescence, storage, ethylene, vase life

Abstract. Physostegia purpurea Blake is a native, herbaceous perennial that has potential as a field-grown cut flower. Physostegia stems were harvested with one third of the florets open and were recut underwater in the laboratory. Fresh cut flowers treated with silver thiosulfate (STS) and held in a $2 \%$ preservative solution lasted 14 days, while control stems in deionized water (DI) lasted 6 days. Cut stems placed in darkness at $\mathrm{OC}$ for 1 week had 8 days of vase life after removal from storage and treatment with STS and preservative, while stems held in DI after storage lasted only 4 days. Stems held dry at $22.5 \mathrm{C}$ and $43 \% \mathrm{RH}$ for 8 hours before being placed in preservative had similar vase life as flowers placed in preservative immediately after harvest.

Field production of cut flowers has evoked renewed interest in recent years. Annual and perennial herbaceous garden plants have received increased emphasis as potential cut flower crops. A major problem encountered in the field production of these crops is that very little cultural or postharvest handling information is available.

Physostegia purpurea is a herbaceous perennial that has potential as a cultivated cut flower. The species is adapted to moist, low areas and flowers abundantly in purple spikes during April and May in the southern United States. The flower buds, $\approx 40$ per stem, mature acropetally. The main characteristics that recommend $P$. purpurea's use as a cut flower are an upright growth habit, with an abundance of attractive flowers on long, sturdy stems, and early flowering. These traits may allow producers to take advantage of seasonally higher prices for cut flowers.

If a cut flower is to be successfully marketed, the postharvest handling techniques

Received for publication 23 Jan. 1989. Technical contribution no. 3022 of the South Carolina Agricultural Experiment Station, Clemson Univ. The cost of publishing this paper was defrayed in part by the payment of page charges. Under postal regulations, this paper therefore must be hereby marked advertisement solely to indicate this fact.

${ }^{1}$ Associate Professor. To whom reprint requests should be addressed.

${ }^{2}$ Assistant Professor. must be determined, but no information has been published on $P$. purpurea. The objective of this research was to determine the effects of silver thiosulfate (STS), commercial preservative, ethylene, and storage on longevity of $P$. purpurea cut flowers.

$P$. purpurea stems were harvested from field plantings in late April and experiments were repeated in early May. Based on results from preliminary experimentation, all stems were harvested with about one third of the flowers open. Cut flowers were immediately transported to the laboratory and stems were cut under deionized water (DI) to $50 \mathrm{~cm}$. The indicates mean $\pm \mathrm{SE}$. lower one third of the foliage was removed and plants were handled as described below.

Vase life determinations. Cut stems were treated individually in graduated test tubes with either $2 \mathrm{mM}$ STS or DI until each stem had absorbed $1 \mathrm{ml}$ of solution. Silver thiosulfate was prepared as described by Cameron and Reid (1981). Three replications of five samples each from the treatments were placed individually in either $0,10.5$, or 21 $\mathrm{g}$ Florever/liter, a preservative solution (Floralife, Chicago), made up with DI water. Cut flowers were evaluated at $22.5 \pm 1.5 \mathrm{C}, 45 \%$ $\pm 10 \% \mathrm{RH}$, and $16.7 \pm 1.5 \mu \mathrm{mol} \cdot \mathrm{s}^{-1} \cdot \mathrm{m}^{-2}$ photosynthetic photon flux (PPF) from coolwhite fluorescent lights with a 24-hr photoperiod. Cut stems were maintained until vase life was considered terminated, which was when one half of the florets on a stem had wilted.

Ethylene sensitivity. Ten stems per treatment were cut under water to $15 \mathrm{~cm}$ and placed individually into graduated test tubes containing $1 \mathrm{ml}$ of either $2 \mathrm{mM}$ STS or DI. Based on data from a preliminary screening and the preservative study noted above, each flower stem was carefully monitored and allowed to take up $0.3 \mathrm{ml}$ of either STS or DI and then was placed in a $2 \%$ preservative solution. Cut stems were held under the environmental conditions described above. At $\approx 1000$ HR each day, stems were weighed and placed in 25-ml Ehrlenmeyer flasks that were mounted inside a 0.94-liter glass jar and contained $20 \mathrm{ml}$ of preservative solution. The lid of the jar was equipped with a rubber serum stopper for gas sampling. Internal atmosphere of the glass jars was flushed with compressed air for $5 \mathrm{sec}$ before sealing. After $2 \mathrm{hr}$, l-ml gas samples were removed and

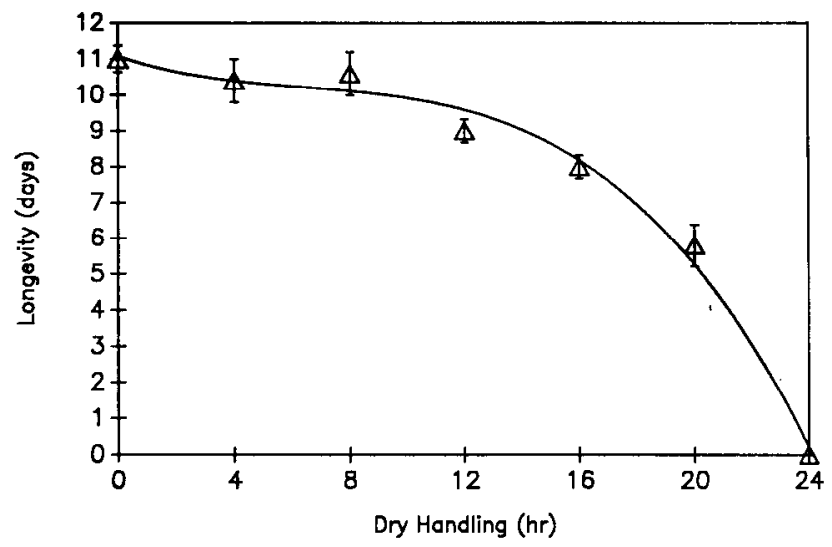

Fig. 1. Longevity of Physostegia purpurea as affectcd by duration of dry handling at 22.5C. Bar 
Table 1. Vase life of Physostegia as affected by postharvest treatment.

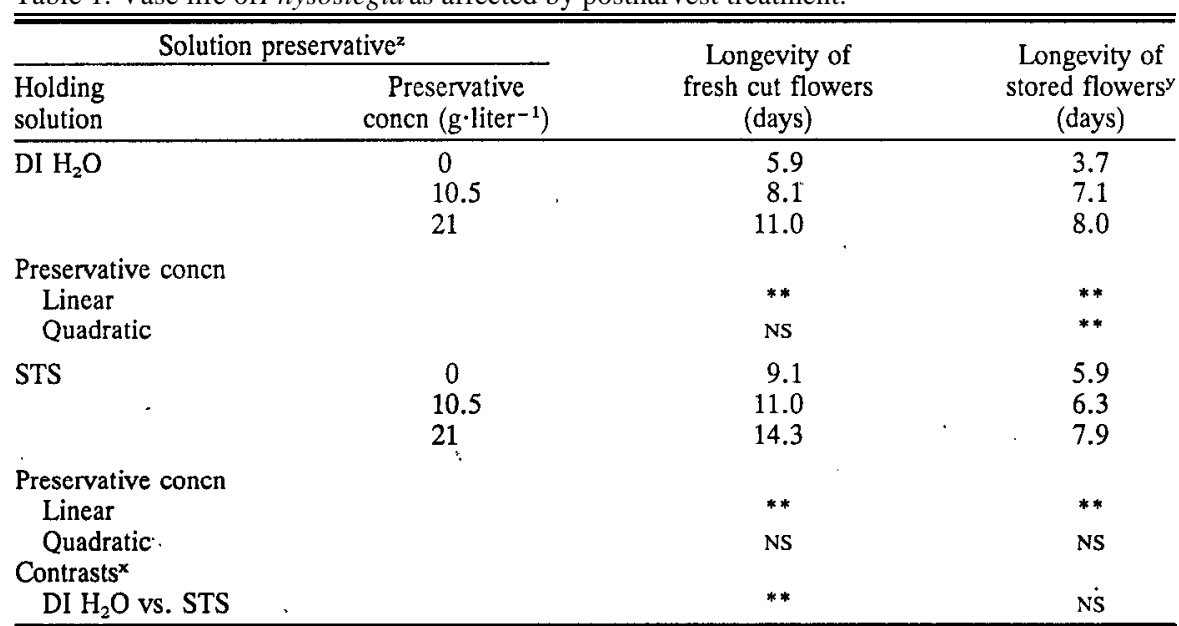

${ }^{2} \mathrm{DI}=$ deionized water; $\mathrm{STS}=$ silver thiosulfate at $2 \mathrm{~mm}$; preservative $=$ Florever .

'Flowers stored for 7 days at $0 \mathrm{C}$ before evaluation.

${ }^{x}$ Single-degrees-of-freedom contrasta.

,*,**Nonsignificant or significant at $P=0.05$ or 0.01 , respectively.

analyzed for ethylene by a gas chromatography equipped with a flame ionization detector.

Cold storage. Flowers were harvested as described above, except stems were cut to $55 \mathrm{~cm}$ under DI water. Cut stems were placed in $2 \mathrm{mM}$ STS or DI until $1 \mathrm{ml}$ of solution had been absorbed. All flowers were allowed to absorb an additional $1 \mathrm{ml}$ of DI and then were stored dry in a loosely sealed, black polyethylene film vapor barrier and stored in the dark for 7 days at $0 \pm 0.5 \mathrm{C}$. After removal from storage, three replications of five samples each from each pretreatment (STS or DI) were cut under water to $50 \mathrm{~cm}$ and placed in preservative solution (Florever at $0,10.5$, or $21 \mathrm{~g} \cdot \operatorname{liter}^{-1}$ ) for determination of longevity. Flowers were evaluated in environmental conditions as described previously. All data from the above experiments were subjected to regression analysis.

Dry handling. Flowers were harvested at $0830 \mathrm{HR}$ and immediately transported to the laboratory. Flowers were cut to $55 \mathrm{~cm}$ and held dry at $22.5 \pm 1.5 \mathrm{C}, 45 \% \pm 10 \% \mathrm{RH}$, and $16.7 \pm 1.5 \mu \mathrm{mol} \cdot \mathrm{s}^{-1} \cdot \mathrm{m}^{-2} \mathrm{PPF}$. Fifteen stems were cut under water to $50 \mathrm{~cm}$ every $4 \mathrm{hr}$ and placed in preservative solution $(21$ g.liter $\left.{ }^{-1}\right)$. Vase life was then determined as described earlier.

Once an individual bud opened, the individual flower lasted $\approx 2$ to 3 days. The aesthetic value of Physostegia is due to both continued development of buds and longevity of individual opened flowers.

Preservative solution, STS, and cold stor- age. The addition of a preservative to the holding solution increased the longevity of Physostegia (Table 1). There was a linear increase in vase life as preservative concentration increased in all treatments. Silver thiosulfate treatment increased longevity in fresh cut flowers, but there was no benefit from STS treatment when stored flowers were subsequently held in a preservative solution.

Florets on the STS-treated stems seemed to retain their purple pigment better than stems not treated with STS, where petal color faded with time. Silver thiosulfate-treated stems also seemed to have less floret abscission, even after florets had senesced, although we did not record relevant data. Silver thiosulfate has been shown to inhibit flower abscission in other species (Cameron and Reid, 1981, 1983; Thaxton et al., 1988).

Ethylene. No ethylene production was detectable at any stage during senescence (data not shown). The gas chromatography had a sensitivity of $50 \mathrm{nl}$ ethylene/liter air. Possibly, the volume of the sealed container $(\approx 1$ liter) was too large to allow sufficient buildup of ethylene. However, using a smaller container would have risked mechanical injury to the petals of the cut flowers. Increasing the duration that the flowers were sealed (4 hr) did not result in production of any detectable ethylene. Ethylene production has been shown to increase in many cut flower crops during senescence (Halevy and Mayak, 1981) and this ethylene production often contributes to early senescence of the exposed flowers. Physostegia fresh weight did not change during the ethylene-sampling experiment

To further investigate the effects of ethylene on Physostegia longevity, cut flowers were placed in DI and sealed in a 10-liter plexiglass chamber and exposed to $1 \mu$ ethylene/liter air. No visible injury was observed after 12 or $24 \mathrm{hr}$ of exposure and longevity of the cut flowers was not affected by ethylene treatment.

The data appear to indicate that exogenous ethylene is not a major factor contributing to the senescence of cut Physostegia stems, as is the case for other flowers (Mayak and Halevy, 1981). Silver thiosulfate, however, did extend longevity of cut Physostegia. Paul and Goo (1982) found STS to have beneficial effects other than its direct effect on ethylene action. They concluded that STS reduced stem microbial organisms and ethylene-related wound responses that lead to stem blockage and inhibition of water transport.

Dry handling. Field harvesting of cut flowers often results in the severed stems being left out of water for an extended time. A cut flower that tolerates dry handling for extended periods at an elevated temperature would be desirable. When Physostegia stems were held at $22.5 \mathrm{C}$, recut under water, and placed in a $2 \%$ preservative solution, the longevity was not affected until flowers had been held dry for more than $8 \mathrm{hr}$ (Fig. 1). These data indicate that Physostegia maybe adaptable to dry handling after harvest.

Our results indicate that Physostegia purpurea can be handled successfully during simulated postharvest storage, and vase life may be increased by use of STS and preservatives. This species appears to have sufficient postharvest longevity to recommend commercial production, but the market potential of the crop needs to be fully investigated.

\section{Literature Cited}

Cameron, A.C. and M.S. Reid. 1981. The usc of silver thiosulfate anionic complex as a foliar spray to prevent flower abscission of zygocactus. HortScience 16:761-762.

Cameron, A.C. and M.S. Reid. 1983. Use of silver thiosulfate to prevent flower abscission from potted plants. Scientia Hort. 19:373-378.

Halevy, A. and S. Mayak. 1981. Senescence and postharvest physiology of cut flowers. Hort. Rev. 3:59-143.

Paul, R.E. and T. Goo. 1982. Pulse treatment with silver nitrate extends vase life of anthuriums. J. Amer. Soc. Hort. Sci. 107(5):842-844.

Thaxton, D. R., J.W. Kelly, and J.J. Frett. 1988. Control of Hibiscus rosa-sinensis L. bud abscission during shipping. Scientia Hort. 34:131137. 